\title{
Response of epibenthic faunal assemblages to varying vegetation structures and habitat patch size
}

\author{
Emma Nohrén*, Elisabeth Odelgård
}

Department of Marine Ecology, University of Gothenburg, Kristineberg 566, 45034 Fiskebäckskil, Sweden

\begin{abstract}
Vegetation in shallow coastal marine systems increases habitat complexity and attracts epibenthic fauna. However, these areas are often subjected to dynamic changes such as eutrophication and sedimentation, which may lead to a reduction in patch size and/or a shift in species composition; although, few studies have been performed to show how these alterations affect the fauna assemblages. The aim of this study was to examine whether 4 structurally different types of vegetation, Fucus vesiculosus, Sargassum muticum, Zostera marina and filamentous algae, attract a unique assemblage of epibenthic fauna, compared to each other and to bare sand. Further, the importance of patch size $\left(0.25,0.5,1.0\right.$ and $\left.2.0 \mathrm{~m}^{2}\right)$ on faunal species richness, biomass and assemblage composition within the different vegetation types was investigated. Experimental patches of vegetation were placed in a bay and samples were retrieved after $72 \mathrm{~h}$. Pairwise tests (presence/absence data) showed that the faunal assemblages were significantly different between the vegetation types and also bare sand. Further, the 3 algal treatments (but not the seagrass $Z$. marina treatment) attracted higher species richness and a higher biomass of motile epibenthic fauna compared to the bare sand habitat. Among the 4 macrophytes, $S$. muticum, an invasive species found within the study area, and $F$. vesiculosus attracted the highest species richness and biomass, which suggests that the cooccurrence of these 2 species (in the absence of space or nutrient competition) results in an important habitat for epibenthic fauna. There was no overall effect of patch size, although within the $F$. vesiculosus and $Z$. marina treatments, patch size-dependent variations were found.
\end{abstract}

KEY WORDS: Epibenthic fauna $\cdot$ Macrophytes $\cdot$ Habitat complexity $\cdot$ Patch size $\cdot$ Habitat functioning Resale or republication not permitted without written consent of the publisher

\section{INTRODUCTION}

Shallow, soft-sediment habitats are important within coastal marine ecosystems, particularly for young fish and marine invertebrates (Muus 1967, Zijlstra 1972, Pihl \& Rosenberg 1982, Baden \& Pihl 1984, Möller et al. 1985, Pihl 1989). These habitats often contain a mosaic of structurally complex microhabitats, e.g. eelgrass, blue mussel patches and large macrophytes attached to secondary hard substrata like stones or shell debris (Norling \& Kautsky 2007). Microhabitats are important for epibenthic faunal assemblages, especially during larval settlement (Moksnes 2002).

Macroalgae increase the habitat complexity of shallow, soft-sediment habitats and provide more niches for organisms through the creation of additional space and shelter, in addition to providing a substrate for epi- phytic fauna and flora which support high densities of organisms and increase biodiversity (Duggins et al. 1989, Brawley 1992, Arrontes 1999, Fredriksen et al. 2005, Norling \& Kautsky 2007). For example, Nohrén et al. (2009) showed a significant effect of vegetation cover on faunal biomass and number of faunal species, and Wennhage \& Pihl (2007) found a higher faunal biomass in vegetated areas compared to bare sand.

Coastal habitats are dynamic and the algae composition may shift between years from seaweed to filamentous algae (Wennhage \& Pihl 2007); in addition, continuous eelgrass meadows can fragment and/or disappear from one place while new meadows may be generated at other sites (Baden et al. 2003). These dynamic changes are often caused by natural events (Robbins \& Bell 1994, Hovel \& Lipcius 2001), but may also be the result of anthropogenic activities such as 
eutrophication (Short \& Burdick 1996), sedimentation from coastal development (Fonseca \& Bell 1998) or boating and fishing (Sargent et al. 1995). When macrophyte habitats are fragmented, the algal species composition may change if new algae with different morphologies replace the original species, which in turn can alter the dynamic patterns of associated fauna and lead to a shift in species composition (Isaksson \& Pihl 1992, Wennhage \& Pihl 2007). Change in vegetation habitat structure can also create patchy environments, which may alter the ecological activity, abundance and distribution of species (Fahrig 2003). A habitat comprised of small patches can substantially differ in such aspects from larger continuous habitats, and many studies have focused on how fauna respond to patchy habitats, especially in eelgrass meadows (see Bell et al. 2001 for review), but there are also studies from mussel beds (Tsuchiya \& Nishihira 1985, Lintas \& Seed 1994, Ragnarsson \& Raffaelli 1999), oyster reefs (Eggleston et al. 1998) and subtidal kelps (Bologna \& Steneck 1993).

Although macrophytes are known to increase faunal species richness and biomass, few studies have adopted an experimental approach to investigate how seascape configurations affect marine organisms and of those, most have been limited to seagrass habitats and large scales. Bell et al. (2001) reviewed 24 studies that investigated resident fauna responses to seagrass patch size but found no consistent impact of spatial scale on faunal response. Most of the reviewed articles had investigated at large spatial scales (5 to $\left.>5000 \mathrm{~m}^{2}\right)$; however, Eggleston et al. (1998), also included in the Bell et al. (2001) review, studied both eelgrass and shell patches on a smaller scale $\left(0.25\right.$ to $\left.4 \mathrm{~m}^{2}\right)$. This latter small-scale study recorded significantly higher densities of grass shrimp in the smallest patch size, while juvenile blue crab densities were significantly higher in the largest patches. Thus, in the present study we examined small spatial scales using 4 morphologically different macrophyte types, common on Swedish shores, which create differences in habitat complexity and structure.

The aim of the present study was to examine whether the 4 structurally different types of vegetation attracted unique assemblages of epibenthic fauna, compared to each other and to bare sand in shallow waters. Further, the importance of patch size for faunal species richness, biomass and assemblage composition within the different vegetation types was investigated. Our hypotheses were: (1) vegetated habitats will have higher faunal species richness and greater biomass compared to bare sand, and the different vegetation types will attract a unique faunal assemblage; and (2) species composition and biomass of fauna will be positively correlated with patch size in all vegetation types investigated. To test these hypotheses, patches of 4 different sizes $\left(0.25\right.$ to $\left.2 \mathrm{~m}^{2}\right)$ of Fucus vesiculosus, Sargassum muticum, Zostera marina and filamentous algae were distributed into the field on sandy sediment. To avoid secondary interactions and additional factors, e.g. growth of epiphytes and fauna which may attract other fauna, the experiment had an exposure time of $72 \mathrm{~h}$.

\section{MATERIALS AND METHODS}

Study site. The experiment was performed in a semiexposed bay, Bökevik (58 $\left.14^{\circ} 52 \mathrm{~N}, 11^{\circ} 26^{\prime} 53 \mathrm{E}\right)$, in the Gullmarsfjord, Sweden, from 25 June to 3 August 2007. The bay has a shallow depth (mean $=0.4 \mathrm{~m}$ ) and is surrounded by a rocky coastline. The bay has a sandy-silt sediment mixed with stones and shell fragments, and the organic content varies spatially between 0.8 and 1.7\% (Pihl 1986, Gibson et al. 1998). Zostera marina covers about $30 \%$ of the shallow $(<1 \mathrm{~m})$ bay, and there are some patches of macroalgae, mainly Fucus spp. The tidal range in this area is small $(<0.2 \mathrm{~m})$. During the experiment, the mean sea level was $+115 \mathrm{~mm}$, the mean sea temperature $17.4^{\circ} \mathrm{C}(1 \mathrm{~m}$ depth) and the mean salinity $23.1 \mathrm{psu}(1 \mathrm{~m}$ depth). Four unvegetated sites with a surface area of 300 to $900 \mathrm{~m}^{2}$ were selected within the bay ( 0.4 to $0.8 \mathrm{~m}$ mean depth), at least $10 \mathrm{~m}$ from existing vegetation, and marked with buoys (Fig. 1).

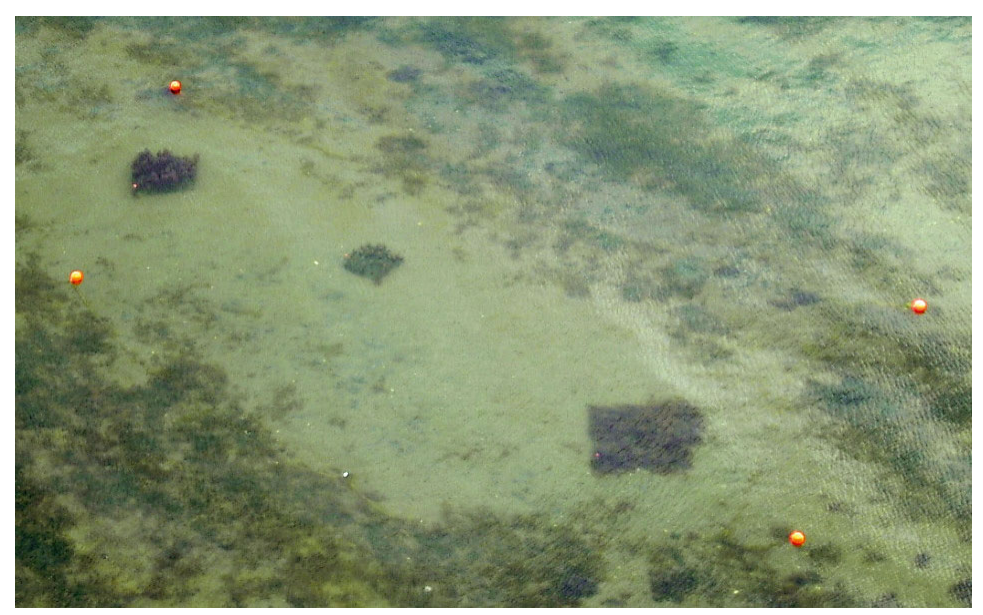

Fig. 1. Experimental area. Orange buoys marked the 4 areas, which were raked clear of any vegetation before and between each treatment. Patches are shown as squares. The whole area consisted of bare sand substrate at the beginning of the experiment; however, as this photo was taken at the end of the experiment, the surrounding seagrass meadow has grown larger 
Study species. Fucus vesiculosus (Fucales, Phaeophyceae) is a perennial brown algae, common on the shores of the northern Atlantic and the northern Pacific, and is present along the entire Swedish west coast down to $\sim 8 \mathrm{~m}$ depth. The plant consists of a flattened, dichotomously branched thallus with a small stipe and a holdfast. It has small gas-filled vesicles which occur in pairs, one on each side of the midrib on the thallus. It can grow to a length up to $100 \mathrm{~cm}$, but in the study area it is rarely larger than $50 \mathrm{~cm}$. It is commonly found on soft-sediment substrates attached to secondary hard substrates (shells and stones) in monospecific even-aged stands and also constitutes an important component of many marine hard substrate ecosystems (Bird \& Benson 1987, Mann 2000).

Sargassum muticum (Fucales, Phaeophyceae) is a large perennial brown alga and its stem has regularly alternating branches with flattened oval blades and spherical gas bladders. The plants attach to secondary hard substrata. This species can grow continually and every single branch is fertile, with the capability to release numerous progeny over large distances (Rueness 1989). It originates from the Japanese Sea but has invaded new waters. The first record from Sweden was of drifting plants in 1985 in the northern part of the Skagerrak archipelago; the first growing plants were recorded in the same area in 1987 (Karlsson \& Loo 1999). Since then, $S$. muticum has become a common and widespread species in Swedish waters on the west coast of the Skagerrak and Kattegat and its distribution continues to expand; drifting plants have been found in the Baltic Sea (SW Baltic Proper) since 2005 (Thomsen et al. 2006).

Filamentous algae is a generic term that defines short-lived algae which form long visible chains, e.g. Cladophora spp., Enteromorpha spp., Dictyosiphon spp. and Pilayella spp. They have a high surface to volume ratio and are characterised by rapid production rates and nutrient uptake compared to perennial species (Wallentinus 1984a,b). During the last few decades, filamentous algae have increased in the Skagerrak, mainly due to eutrophication, and have now become a threat to the coastal areas, changing habitat structure or causing local hypoxia (Wennberg 1987 , Norkko 1998, Pihl et al. 1999). Heavy overgrowth of filamentous algae may result in a reduction of faunal abundance or a shift in faunal species composition but they may also provide refugia which reduce the risk of predation (Isaksson \& Pihl 1992, Wennhage \& Pihl 2007).

Eelgrass Zostera marina (Alismatales, Monocots) is a phanerogam with buried roots and leaves that are 2 to $10 \mathrm{~mm}$ wide and 200 to $1200 \mathrm{~mm}$ long, usually found at 0.5 to $5 \mathrm{~m}$ depth. It is widespread in the Northern Hemisphere and occurs throughout the Skagerrak coastal region. Growth and development of a natural seagrass bed occurs via both germination of seedlings and vegetative propagation, thus resulting in a mosaic of patches separated by unvegetated bare bottom (den Hartog 1971, Thayer et al. 1984, Duarte \& Sand-Jensen 1990). The ecological importance of $Z$. marina has long been recognized as beds of this species represent habitats of high primary productivity and support high faunal biodiversity (Baden \& Boström 2001). Monitoring of eelgrass beds has shown that the distribution along the Skagerrak coast may have decreased by around $60 \%$ over the last 2 decades (Baden et al. 2003).

Experimental design. The macrophytes were collected by free-divers within $2.5 \mathrm{~km}$ of the experimental area. Once at the laboratory, every plant and blade was cleared of epiphytes and any other attached animals then placed in clean filtered seawater overnight.

Plastic garden nets with $50 \mathrm{~mm}$ squares were used as attachment surface for macrophytes. The nets were cut into squares of 2 sizes $(0.5 \times 0.5$ and $0.7 \times 0.7 \mathrm{~m})$ and the rinsed macrophytes were attached to the nets with cable ties, plant by plant, simulating natural plant density and height. The quantity of vegetation used per $\mathrm{m}^{2}$ was first examined in a pilot experiment, with the attempt to mimic natural conditions in shallow (0 to $1 \mathrm{~m}$ depth) waters; the method was thereby standardized to volume of vegetation per $\mathrm{m}^{2}$ (Fucus vesiculosus $520 \mathrm{cl}$ $\mathrm{m}^{-2}$, Sargassum muticum $240 \mathrm{cl} \mathrm{m}^{-2}$, filamentous algae $280 \mathrm{cl} \mathrm{m}^{-2}$, and Zostera marina $120 \mathrm{cl} \mathrm{m}^{-2}$ ). Treatments are hereafter referred to as Fv (F. vesiculosus), Sm (S. muticum), Zm (Z. marina), Fa (filamentous algae), Cn (control net) and Cs (control bare sand).

Four different patch sizes $\left(0.25,0.5,1.0\right.$ and $\left.2.0 \mathrm{~m}^{2}\right)$ of each vegetation type ( $\mathrm{Fv}, \mathrm{Sm}, \mathrm{Fa}$ and $\mathrm{Zm})$ and control nets without macrophytes $(\mathrm{Cn})$ were placed in the bay for $72 \mathrm{~h}$ on each occasion. In addition, 4 sand patches of corresponding sizes were marked on every occasion (Cs). A pilot experiment determined the exposure time of $72 \mathrm{~h}$, i.e. the time necessary for stabile colonisation, but still short enough to avoid introduction of additional factors such as growth of epiphytic algae, bryozoans and hydroids. The experiment was repeated 5 times (Times A to E) during July and August 2007; to ensure the sediment surface of the experimental areas was vegetation free, they were thoroughly weeded with rakes $1 \mathrm{wk}$ before the experiment started and before all introductions of experimental patches in the field. Patch sizes are hereafter referred to as Size 1 $\left(0.25 \mathrm{~m}^{2}\right), 2\left(0.5 \mathrm{~m}^{2}\right), 3\left(1.0 \mathrm{~m}^{2}\right)$ and $4\left(2.0 \mathrm{~m}^{2}\right)$. Simulated vegetation patches were constructed in the bay by anchoring mats to the sediment surface separately (Sizes 1 and 2) or in groups of 4 (Sizes 3 and 4), secured by $40 \mathrm{~cm}$ long hooks into the sediment in each corner of a mat (Fig. 2). The patches were marked individually with a small buoy. 

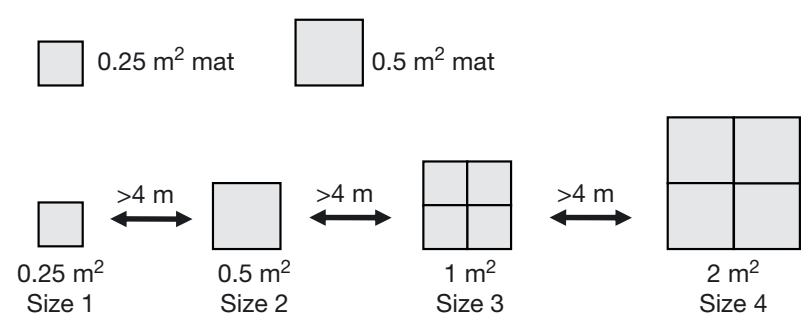

Fig. 2. Schematic illustration of the experimental design. Four mats of Size 1 were put together to create Size 3 and 4 mats of Size 2 were put together to create Size 4. Each treatment was randomly distributed in the bay, within 4 areas cleared of vegetation being $>4 \mathrm{~m}$ apart

Sampling procedure. The patches were sampled with a drop trap $\left(\varnothing=0.125 \mathrm{~m}^{2}, 1 \mathrm{~m}\right.$ height, two $2 \mathrm{~m}$ handles) which was placed within the patch and then emptied into a sieve ( $0.5 \mathrm{~mm}$ mesh size) using a suction sampler driven by a petrol-powered pump (Honda WB $20 X_{;} 5001 \mathrm{~min}^{-1}$ ). The drop trap was never submerged nor vacuumed dry during sampling due to constructed net-covered openings on each side (1 mm mesh size). Fauna were immediately sifted out from the net and preserved in $70 \%$ ethanol. In the laboratory, all fauna were identified to species level, individual length and biomass were recorded and species abundances were determined (due to uncertain identification of young and small individuals, species within the family Gammaridae were not identified further than family level). Biomass of each sample was calculated from a regression of length and ash-free dry weight (AFDW) (Nohrén et al. 2009).

Statistical analysis. Differences in species richness (i.e. number of species) and biomass among sampling occasions and patch sizes were tested using 1-way ANOVA (SPSS 16.0); in addition, a Tukey's post hoc test was performed when significant differences were found. Biomass data were square root-transformed to reduce skewness and improve homogeneity of variances.

Differences in faunal composition between treatments, patch sizes and times were investigated using permutational multivariate ANOVA (PERMANOVA; Anderson 2001, McArdle \& Anderson 2001), here used as an add-on program to the multivariate statistical analysis program package PRIMER 6.0 (Clarke \& Warwick 1994). One sample (Cs, Size 2, Time D) did not contain any specimens and was removed from all multivariate statistical calculations, as suggested by Clarke \& Gorley (2006). Abundance data were untransformed, but biomass data were square roottransformed to balance the contribution from small and/or heavy taxa. In addition, a presence/absence transformation was performed to investigate community patterns irrespective of abundance. The biomass and abundance analyses were based on Bray-Curtis dissimilarities and presence/absence analyses were based on the Sørensen index.

A similarity percentage (SIMPER) analysis (species contribution to similarity) was carried out on the presence/absence data set to determine which species in the faunal assemblage were most responsible for the Bray-Curtis dissimilarity/Sørensen index within groups and dissimilarity between groups.

\section{RESULTS}

\section{Fauna}

A total of 22 taxa were examined, of which 14 were found in Fv and Sm treatments, 11 in Fa and Zm treatments and 6 in the 2 controls (Table 1). Nassarius nitidus was the most common species and occurred in almost every sample of each treatment, followed by Crangon crangon, Pleuronectes platessa and Littorina littorea. Several taxa only occurred once or twice in the

Table 1. Occurrence of taxa among samples $(n=20)$ in each treatment and total number of species per treatment. Fv: Fucus vesiculosus; Sm: Sargassum muticum; Fa: filamentous algae;

Zm: Zostera marina; $\mathrm{Cn}$ : control net; Cs: control bare sand

\begin{tabular}{|c|c|c|c|c|c|c|}
\hline \multirow[t]{2}{*}{ Species/taxon } & \multirow[b]{2}{*}{$\mathrm{Fv}$} & \multicolumn{3}{|c|}{ - Treatment } & \multirow[b]{2}{*}{$\mathrm{Cn}$} & \multirow[b]{2}{*}{ Cs } \\
\hline & & $\mathrm{Sm}$ & $\mathrm{Fa}$ & $\mathrm{Zm}$ & & \\
\hline \multicolumn{7}{|l|}{ Mollusca } \\
\hline Littorina littorea & 9 & 11 & 11 & 10 & 3 & 1 \\
\hline Littorina fabalis & 1 & 1 & & & & \\
\hline Littorina obdusata & 3 & & & & & \\
\hline Nassarius nitidus & 20 & 19 & 20 & 20 & 18 & 17 \\
\hline Leptochitona cinera & 1 & & & 1 & & \\
\hline \multicolumn{7}{|l|}{ Arthropoda } \\
\hline Idotea baltica & & & 1 & & & \\
\hline Gammaridae & 3 & 2 & 9 & & & \\
\hline Palaemon adspersus & 4 & 12 & 10 & 1 & & \\
\hline Palaemon elegans & 3 & 9 & 3 & 2 & 2 & \\
\hline Pagurus bernhardus & & & & 1 & & \\
\hline Carcinus maenas & 3 & 3 & 9 & & 2 & \\
\hline Macropodia rostrata & & 1 & & & & \\
\hline Crangon crangon & 3 & 7 & 7 & 12 & 13 & 16 \\
\hline Pranus flexuosus & & & & & & 1 \\
\hline \multicolumn{7}{|l|}{ Echinodermata } \\
\hline Asterias rubens & 2 & & 1 & & & \\
\hline \multicolumn{7}{|l|}{ Pisces } \\
\hline Pomatoschistus sp. juv. & & & 1 & 1 & & \\
\hline Pomatoschistus minutus & 1 & & & & & 2 \\
\hline Pleuronectes platessa & 10 & 7 & 4 & 4 & 8 & 4 \\
\hline Syngnathus acus & & 1 & & & & \\
\hline Syngnathus rostellatus & & 2 & & 1 & & \\
\hline Syngnathus typhle & 6 & 1 & & 5 & & \\
\hline Symphodus melops & & 1 & & & & \\
\hline Total no. taxa & 14 & 14 & 11 & 11 & 6 & 6 \\
\hline
\end{tabular}



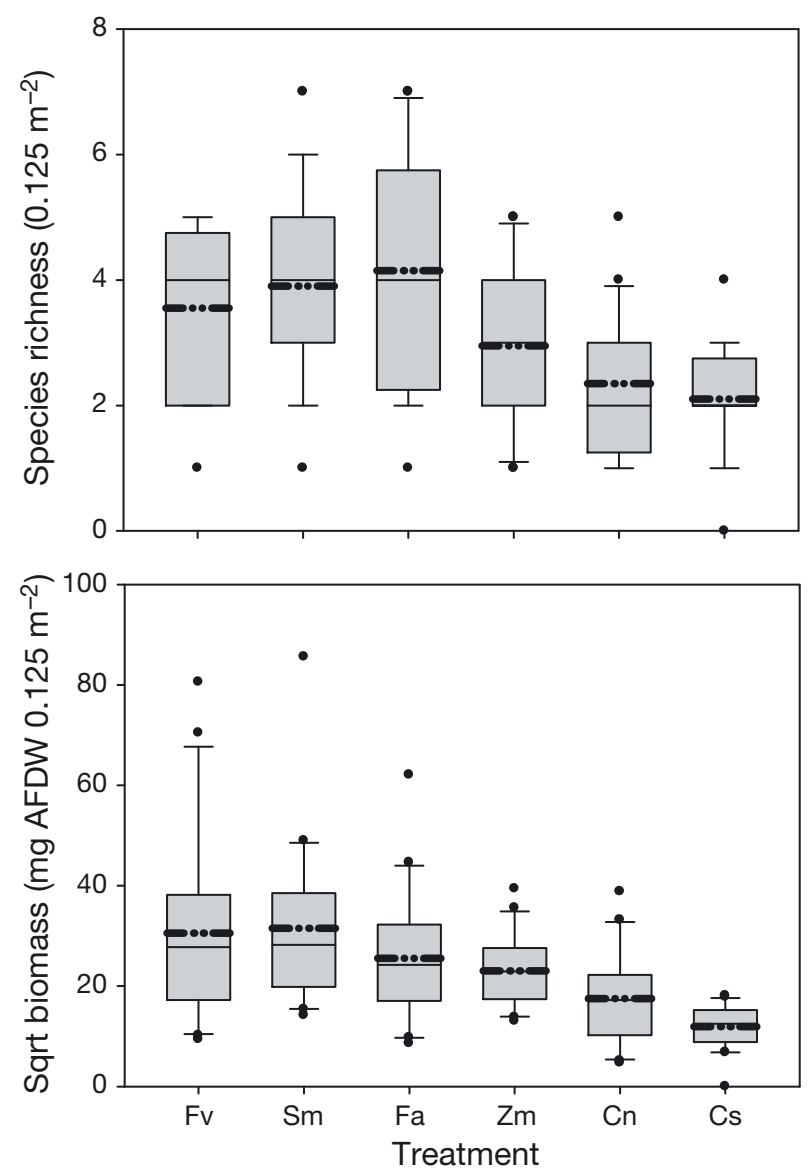

Fig. 3. Boxplot of species richness and biomass (square roottransformed) for each treatment (Fv: Fucus vesiculosus; Sm: Sargassum muticum; Zm: Zostera marina; Fa: filamentous algae; $\mathrm{Cn}$ : control net; Cs: control bare sand). The boxes indicate the 25th and 75th percentiles; thick, broken lines show means; thin lines mark the median. Error bars indicate the 90th and 10th percentiles; dots mark outliers. AFDW: ash-free dry weight

sampling, e.g. Leptochitona cinera, Littorina fabalis, Pranus flexuosus, Macropodia rostrata, Pagurus bernhardus, Idotea baltica, Syngnathus acus and Symphodus melops.

There were significant differences in species richness between treatments (ANOVA, $F=7.96, \mathrm{df}=5, \mathrm{p}<0.001$ ). Tukey's post hoc test showed that species numbers were significantly ( $\mathrm{p}<$ 0.05) higher in the Fv, Sm and Fa treatments compared to $\mathrm{Cs}$, and significantly higher in Sm and Fa compared to $\mathrm{Cn}$ (Fig. 3). There was a trend bordering on significance $(p=0.055)$ of a higher number of species found in $\mathrm{Fv}$ compared to $\mathrm{Cn}$.

Faunal biomass also differed significantly between treatments (ANOVA, $F=7.45, \mathrm{df}=5, \mathrm{p}<0.001)$ and Tukey's post hoc test showed the same pattern with significantly $(\mathrm{p}<0.05)$ higher biomass in algal treatments compared to controls ( $\mathrm{Cs}<\mathrm{Fv}$, Sm and $\mathrm{Fa}$; $\mathrm{Cn}<\mathrm{Fv}$ and Sm; Fig. 3).

\section{Faunal assemblages}

The PERMANOVA showed an overall effect of treatment on the faunal assemblage for biomass and abundance, but no effect of patch size or time (Table 2). Pairwise tests showed that most treatments differed significantly from each other according to faunal assemblage. The 2 control treatments were not significantly different in any of the 3 data sets, and $\mathrm{Cn}$ and $\mathrm{Zm}$ in the presence/absence and biomass data sets and $\mathrm{Fv}$ and $\mathrm{Sm}$ in the abundance and biomass data sets also could not be statistically separated (Table 3 ).

Similarity analysis within treatments based on presence/absence data was undertaken in order to investigate which species contributed most to the different faunal assemblages. All treatments showed high $(>46 \%$ ) similarities within assemblages and the 2 controls had the highest similarity ( $>60 \%$; Table 4$)$. Nassarius nitidus contributed to the highest similarity $(\geq 50 \%$ ) within all treatments and $N$. nitidus together with Crangon crangon made up $98 \%$ of the similarity in the Cs treatment. N. nitidus and Littorina littorea contributed most to the similarities seen between the 4 different vegetation types, and the faunal assemblage in the $\mathrm{Cn}$ treatment consisted of $N$. nitidus, $C$. crangon and Pleuronectes platessa (Table 4).

The dissimilarity in faunal assemblages among treatments based on presence/absence data was large (>50\%), except between Cs and Zm (41.7\%), Cs and $\mathrm{Cn}(36.2 \%)$ and $\mathrm{Cn}$ and $\mathrm{Zm} \mathrm{(43.5 \% ;} \mathrm{Table} \mathrm{5).} \mathrm{The}$ largest dissimilarity was found between the Cs treatment and the 3 algal treatments (Fv-Cs 58.3\%, Sm-Cs $58.1 \%$, Fa-Cs 56.0\%). Crangon crangon contributed

Table 2. Three-way permutational multivariate analysis of variance based on Bray-Curtis dissimilarity matrix (abundance and biomass data) and Sørensen's index (presence/absence data) of square root-transformed biomass data and untransformed abundance data. p-values were obtained using 9999 random permutations. ${ }^{*} \mathrm{p}<0.05 ;{ }^{* *} \mathrm{p}<0.01 ;{ }^{* * *} \mathrm{p}<0.001$; ns: not significant $(\mathrm{p}>0.05)$

\begin{tabular}{|c|c|c|c|c|c|c|c|}
\hline \multirow{2}{*}{ Parameter } & \multirow[t]{2}{*}{ df } & \multicolumn{2}{|c|}{ Presence/absence } & \multicolumn{2}{|c|}{ Abundance } & \multicolumn{2}{|c|}{ Biomass } \\
\hline & & MS & $F$ & MS & $F$ & MS & $F$ \\
\hline Treatment & 5 & 7693.7 & $7.54^{* * *}$ & 7893.2 & $5.83^{* * *}$ & 8754.9 & $5.89^{* * *}$ \\
\hline Size & 3 & 1821 & $1.78^{\mathrm{ns}}$ & 1783 & $1.32^{\mathrm{ns}}$ & 2307.5 & $1.55^{\mathrm{ns}}$ \\
\hline Time & 4 & 1414.3 & $1.39^{\mathrm{ns}}$ & 2663.4 & $1.97^{\mathrm{ns}}$ & 2427.7 & $1.63^{\mathrm{ns}}$ \\
\hline Treatment $\times$ Size & 15 & 1683 & $1.65^{*}$ & 1531.1 & $1.13^{\mathrm{ns}}$ & 2028.7 & $1.37^{\mathrm{ns}}$ \\
\hline Treatment $\times$ Time & 20 & 1401.6 & $1.37^{\mathrm{ns}}$ & 1572.4 & $1.16^{\mathrm{ns}}$ & 1892.6 & $1.27^{\mathrm{ns}}$ \\
\hline Size $\times$ Time & 12 & 847.54 & $0.83^{\text {ns }}$ & 1287.1 & $0.95^{\mathrm{ns}}$ & 1328.4 & $0.89^{\text {ns }}$ \\
\hline Residuals & 59 & 1020.6 & & 1352.7 & & 1486.1 & \\
\hline
\end{tabular}


to the largest dissimilarity in all 3 cases, together with Littorina littorea and Pleuronectes platessa (Fv-Cs), Palaemon adspersus (Sm-Cs) and Carcinus maenas (Fa-Cs; Table 5).

The presence/absence analysis visualized a trend that Pleuronectes platessa preferred macrophytes to bare sand substrate. Palaemon sp. showed a preference for Sm and Carcinus maenas and Littorina littorea were more frequent in $\mathrm{Sm}$ than in $\mathrm{Zm}$ patches.

Table 3. Pairwise comparisons between treatments (Fv: Fucus vesiculosus; Sm: Sargassum muticum; Fa: filamentous algae; $\mathrm{Zm}$ : Zostera marina; Cn: control net; Cs: control bare sand) based on Bray-Curtis dissimilarity matrix (abundance and biomass data) and Sørensen's index (presence/absence data) of square root-transformed biomass data and untransformed abundance data. ${ }^{*} \mathrm{p}<0.05 ;{ }^{* *} \mathrm{p}<0.01 ;{ }^{* * *} \mathrm{p}<0.001 ;$ ns: not significant $(\mathrm{p}>0.05)$

\begin{tabular}{|lccc|}
\hline Groups & $\begin{array}{c}\text { Presence/absence } \\
t\end{array}$ & $\begin{array}{c}\text { Abundance } \\
t\end{array}$ & $\begin{array}{c}\text { Biomass } \\
t\end{array}$ \\
\hline Fv-Sm & $1.77^{*}$ & $1.25^{\text {ns }}$ & $1.51^{\text {ns }}$ \\
Fv-Fa & $2.67^{* *}$ & $2.05^{* *}$ & $2.16^{* *}$ \\
Fv-Zm & $2.23^{* *}$ & $1.75^{*}$ & $1.73^{*}$ \\
Fv-Cn & $2.58^{* *}$ & $1.81^{*}$ & $1.96^{*}$ \\
$\mathrm{Fv}-\mathrm{Cs}$ & $4.45^{* * *}$ & $2.85^{* * *}$ & $3.17^{* * *}$ \\
$\mathrm{Sm}-\mathrm{Fa}$ & $1.80^{*}$ & $1.99^{* *}$ & $1.73^{*}$ \\
$\mathrm{Sm}-\mathrm{Zm}$ & $2.69^{* *}$ & $2.30^{* *}$ & $2.45^{* *}$ \\
$\mathrm{Sm}-\mathrm{Cn}$ & $4.01^{* * *}$ & $2.37^{* *}$ & $3.02^{* * *}$ \\
$\mathrm{Sm}-\mathrm{Cs}$ & $3.01^{* * *}$ & $2.88^{* * *}$ & $3.13^{* * *}$ \\
$\mathrm{Fa}-\mathrm{Zm}$ & $3.15^{* * *}$ & $3.75^{* * *}$ & $2.91^{* * *}$ \\
$\mathrm{Fa}-\mathrm{Cn}$ & $3.21^{* * *}$ & $2.30^{* *}$ & $2.62^{* * *}$ \\
$\mathrm{Fa}-\mathrm{Cs}$ & $4.66^{* * *}$ & $3.26^{* * *}$ & $3.65^{* * *}$ \\
$\mathrm{Zm}-\mathrm{Cn}$ & $1.44^{\mathrm{ns}}$ & $2.21^{* *}$ & $1.59^{\text {ns }}(\mathrm{p}=0.058)$ \\
$\mathrm{Zm}-\mathrm{Cs}$ & $2.81^{* *}$ & $3.90^{* * *}$ & $2.79^{* * *}$ \\
$\mathrm{Cn}-\mathrm{Cs}$ & $0.69^{\text {ns }}$ & $1.01^{\mathrm{ns}}$ & $0.88^{\text {ns }}$ \\
\hline
\end{tabular}

\section{Patch size}

There was no overall effect of patch size with respect to species richness (ANOVA, $F=0.43$, df $=3, \mathrm{p}>0.05$ ) or biomass $(F=0.43, \mathrm{df}=3, \mathrm{p}>0.05)$. However, within the Fv treatment, patch Size 4 had significantly ( $\mathrm{p}<$ 0.05) higher species richness than Size 2, and in the Zm treatment patch Size 2 had significantly ( $p<0.05$ ) higher biomass than Sizes 1 and 3.

\section{DISCUSSION}

The present study clearly supports our hypothesis that macrophytes attract higher species richness and a higher biomass of motile epibenthic fauna compared to bare sand substrate. These results are in line with other studies from the investigated area (Wennhage \& Pihl 2007, Nohrén et al. 2009). However, a direct comparison with these studies could not be made as they sampled a variety of levels of vegetation coverage, varying between 0 and $100 \%$, randomly within the area, while in the present study the level of vegetation coverage was always $100 \%$.

In the present study, all vegetation patches, even the smallest ones $\left(0.25 \mathrm{~m}^{2}\right)$, had significantly higher species richness and a higher faunal biomass compared to the 2 controls, although Fahrig (2003) argued that due to fragmentation, vegetation patches at some point will be too small to sustain a population of animals and individual territory. According to Fahrig (2003), more fragmentation of a habitat will lead to more edge habitats and a higher probability of organisms entering and leaving the patch.
Table 4. Similarity percentage (SIMPER) analysis of epibenthic fauna within treatments (Fv: Fucus vesiculosus; Sm: Sargassum muticum; Fa: filamentous algae; Zm: Zostera marina; $\mathrm{Cn}$ : control net; Cs: control bare sand) based on presence/absence data. Species contribution to the similarity is given, with a similarity cut-off set at $5 \%$. Average similarity is in parentheses $(\%)$

\begin{tabular}{|lcccccc|}
\hline & \multicolumn{7}{c|}{ Contribution (\%) } \\
Species/taxon & Fv & Sm & Fa & Zm & Cn & Cs \\
& $(46.9)$ & $(49.8)$ & $(53.0)$ & $(57.1)$ & $(60.2)$ & $(69.2)$ \\
\hline Nassarius nitidus & 66.1 & 50.5 & 55.1 & 64.2 & 65.3 & 54.2 \\
Littorina littorea & 10.1 & 13.8 & 12.2 & 11.9 & & \\
$\begin{array}{l}\text { Palaemon elegans } \\
\text { Palaemon adspersus }\end{array}$ & & 8 & & & & \\
Carcinus maenas & & 17.1 & 9.1 & & & \\
$\begin{array}{l}\text { Crangon crangon } \\
\text { Gammaridae }\end{array}$ & & 4.8 & 8.7 & & & \\
Pleuronectes platessa & 12.9 & & 8.3 & & & \\
Syngnathus typhle & 4.2 & & & & 8.7 & \\
Total & 93.4 & 94.2 & 93.4 & 95.7 & 98.6 & 98.1 \\
\hline
\end{tabular}

\section{Faunal assemblages}

Among the 4 macrophytes investigated in the present study, Fucus vesiculosus and Sargassum muticum attracted the highest faunal species richness and biomass, and they also attracted the most similar faunal assemblage, according to abundance and biomass. The dissimilarity in the species composition was due to differences in the occurrence of crustaceans, Littorina littorea and, to some extent, fish species. The introduction of the invasive species $S$. muticum on the Swedish west coast has long been expected to have profound effects on the ecosystems in coastal areas (Isaksson \& Pihl 1992, Karlsson \& Loo 1999). However, our results imply that it may play a similar role as F. vesiculosus for associated fauna and, if they can coexist without 


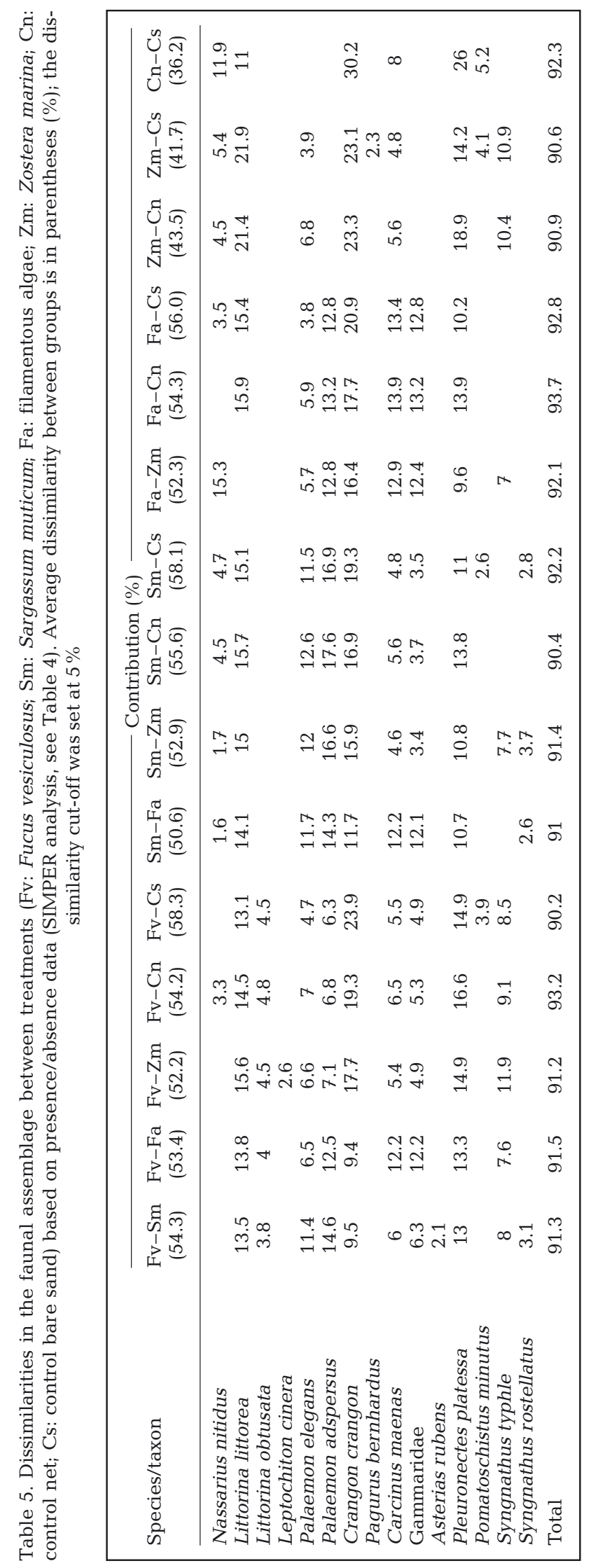

competing for space and nutrient uptake, they may increase the vegetated area and thereby enlarge the area functioning as a refuge, shelter and nursing ground.

The faunal assemblage associated with filamentous algae differed from that found in Sargassum muticum and Fucus vesiculosus, but attracted nearly the same faunal species richness and biomass. Prior studies show that algae can act as refugia for epibenthic prey species; these refugia decrease the predatory success of juvenile cod (Isaksson et al. 1994) and enhance prey survival of polychaetes and decapod crustaceans such as Carcinus maenas, Crangon crangon and other motile fauna (Isaksson \& Pihl 1992, Moksnes et al. 1998). However, the increase of filamentous algae may also be a threat to the faunal community, not only by shifting the faunal composition, but also due to the negative impact on the sediment system. The rapid growth rate of filamentous algae allows them to outcompete and/or overgrow other macrophytes, which completely alters the structure of the habitat; after blooms of these algae, anoxia occurs as a result of their decomposition (Pihl et al. 1991, 1996, Isaksson \& Pihl 1992). An explanation of the high faunal species richness and biomass found in filamentous algae patches in the present study could be the use of solely fresh algae.

No statistically significant differences in abundance, biomass or presence/absence data were noted for the 2 controls, and PERMANOVA results indicated that $\mathrm{Zm}$ treatment differed significantly from Cs but, according to faunal species richness and biomass, not from the Cn treatment. The lack of distinction between the faunal assemblages of Zostera marina and the controls was surprising, since many earlier studies have demonstrated high species richness and faunal biomass in Z. marina meadows (Baden \& Pihl 1984, Heck et al. 1995, Boström \& Bonsdorff 1997, Fredriksen et al. 2005, Pihl et al. 2006). It is also in contradiction to earlier studies where similar faunal richness between $Z$. marina and Fucus serratus has been found (Fredriksen et al. 2005). However, we did not attempt to examine the attraction rate of a fully grown $Z$. marina meadow, which typically has a much higher shoot density than the experimental patches in the present study. Rather, we investigated how fauna respond to fragmented habitats, with a shoot density equal to the shallowest part of a meadow and/or to patches surrounding a fullgrown meadow. If we had used another approach, with greater shoot density, perhaps a result more in line with previous studies would have been obtained.

In the present study, epibenthic fauna such as Carcinus maenas, Crangon crangon, Palaemon adspersus and $P$. elegans, which are characteristic species in Zostera marina habitats (Pihl et al. 2006), were almost 
absent in the Zm treatment, even though these species were found in the other macrophyte treatments. This may be due to the fact that $Z$. marina did not attract fauna at the same speed as other vegetation types, thus the exposure time was too short. Another cause could be the secondary effect of associated fauna attracted by the fauna which first colonize a patch. However, previous studies examining colonization found that faunal densities reached an asymptote after just a few days (Nelson 1979, Stoner \& Lewis 1985, Sogard 1989), and motile marine fauna such as amphipods, decapods and molluscs are known to colonize quickly over large distances (Virnstein \& Curran 1986, Edgar 1992). An alternative explanation may be the presence of a natural $Z$. marina meadow close to the bay near the experimental area. The meadow may have had a 'higher attractiveness' to the Zostera-associated fauna compared to our small and quite low-density patches, while the absence or low number of large macroalgae in the bay would make experimental algae patches more attractive. Earlier studies have shown a correlation between patch size and distance from natural habitats; e.g. Russell et al. (2005) found that the isolation of habitats had a greater effect on polychaete assemblages than on copepods, as may be expected as polychaetes are more limited dispersers than copepods. Further, Roberts \& Poore (2006), who manipulated small stands of Sargassum linearifolium, from a single plant to $1 \mathrm{~m}$ patches, did not find any effect of patch size until they manipulated both habitat patch size and distance, where the abundance of colonizing isopods increased with increasing isolation from contiguous habitat. Other studies on seagrass have also demonstrated that epifaunal survival (Irlandi et al. 1995, Irlandi 1997), density (Hovel \& Lipcius 2002) and diversity (Frost et al. 1999, Healey \& Hovel 2004) differ among existing seagrass meadows that vary in habitat cover and configuration.

\section{Patch size}

Patch size affected faunal species richness in Fucus vesiculosus and faunal biomass in Zostera marina treatments. Although the lack of an overall effect of patch size was contradictory to our hypothesis, our results were in line with earlier studies on macroseaweed. Another study suggests that many small seagrass patches may increase the overall probability of larvae or other immigrant encounters and thereby increase the overall faunal colonization (Eggleston et al. 1999). However, our distance to existing natural habitat may not have been optimal, considering Robert \& Poore's (2006) study of small crustaceans which showed no effect of patch size until they manipulated distance between natural patches. They concluded that the abundance of colonizing isopods increased with increasing distance to the nearest habitat, and amphipods and ostracods preferred small patches over large ones. As our experiment was not isolated from the natural $Z$. marina bed, the surrounding eelgrass meadow may have reduced the attractiveness of the small patches, while species which exhibit a preference for macroalgae could select our experimental algal plots.

The lack of a general patch size effect at the experimental scale used in the present study may also be due to edge effects, since greater fragmentation of a habitat will lead to more edge habitat and a higher probability of organisms entering and leaving the patch (Fahrig 2003). Most studies define edges as the 1 to $4 \mathrm{~m}$ outer perimeter (Bologna \& Heck 1999, Bell et al. 2001, Jelbart et al. 2006); as such the patches used in the present study could be considered as edges without inner content. The algal communities within the present study are frequently fragmented by annual succession which alters their composition and patchiness. For example, a year with heavy ice cover may completely alter the shallow vegetation from one year to another, which in turn affects the faunal assemblage and abundance. As a result, the associated fauna examined in the present study are adapted to this seasonal change in habitat structure, so on the small scale used here it may be difficult to see any pattern or effect. However, if the total vegetation cover in an area is lost or completely fragmented, the present study shows that this will affect the faunal assemblage and thereby the associated predators. This must be taken into account by coastal management policy, as many anthropogenic activities such as eutrophication (Short \& Burdick 1996), sedimentation from coastal development (Fonseca \& Bell 1998) or boating and fishing (Sargent et al. 1995) cause and/or enhance fragmentation.

In conclusion, the present study showed that small algae patches $\left(0.25\right.$ to $\left.2.0 \mathrm{~m}^{2}\right)$ increase the number of faunal species and biomass compared to bare sand substrate and attract a richer faunal assemblage. Varying types of macrophytes attract different faunal assemblages, but there was no overall effect of patch size on motile epibenthic fauna at the scale of 0.25 to $2.0 \mathrm{~m}^{2}$.

Acknowledgements. We are grateful to 2 anonymous referees for useful criticism and suggestions which improved the article's quality and we are grateful for valuable comments from L. Pihl, H. Wennhage, H. Woods and M. Gullström that improved earlier drafts. Further, we thank H. Wennhage, H. Nessie and K. Glada for field assistance. Financial support was provided from Birgit och Birger Wåhlströms minnesfond and Adlerbertska Forskningsstiftelsen. 


\section{LITERATURE CITED}

Anderson MJ (2001) Permutation tests for univariate or multivariate analysis of variance and regression. Can J Fish Aquat Sci 58:626-639

Arrontes J (1999) On the evolution of interactions between marine mesoherbivores and algae. Bot Mar 42:137-155

Baden SP, Boström C (2001) The leaf canopy of seagrass beds: faunal community structure and function in a salinity gradient along the Swedish coast. In: Reise K (ed) Ecological comparisons of sedimentary shores. Ecological studies: analysis and synthesis. Springer-Verlag, Berlin, p 213-236

Baden SP, Pihl L (1984) Abundance, biomass and production of mobile epibenthic fauna in Zostera marina L. meadows, western Sweden. Ophelia 23:65-90

Baden S, Gullström M, Lundén B, Pihl L, Rosenberg R (2003) Vanishing seagrass (Zostera marina, L.) in Swedish coastal waters. Ambio 32:374-377

Bell SS, Brooks RA, Robbins BD, Fonseca MS, Hall MO (2001) Faunal response to fragmentation in seagrass habitats: implications for seagrass conservation. Biol Conserv 100: 115-123

Bird KT, Benson PH (1987) Seaweed cultivation for renewable resources, Elsevier Science, New York

Bologna PAX, Heck KL (1999) Differential predation and growth rates of bay scallops within a seagrass habitat. J Exp Mar Biol Ecol 239:299-314

Bologna PAX, Steneck RS (1993) Kelp beds as habitat for American lobster Homarus americanus. Mar Ecol Prog Ser 100:127-134

Boström C, Bonsdorff E (1997) Community structure and spatial variation of benthic invertebrates associated with Zostera marina (L.) beds in the northern Baltic Sea. J Sea Res 37:153-166

Brawley SH (1992) Mesoherbivores. In: John DM, Hawkins SJ, Price JH (eds) Plant-animal interactions in the marine benthos. Clarendon Press, Oxford, p 235-263

Clarke KR, Gorley RN (2006) PRIMER v6: user manual/tutorial. PRIMER-E, Plymouth

Clarke KR, Warwick RM (1994) Similarity-based testing for community pattern: the two-way layout with no replication. Mar Biol 118:167-176

den Hartog C (1971) The dynamic aspect in the ecology of sea-grass communities. In: Zavodnik D (ed) Sixth European Symposium on Marine Biology, 27 Sep-2 Oct 1971, Rovinj, Yugoslavia. Thalassia Jugosl, Croatia, p 101-112

Duarte CM, Sand-Jensen K (1990) Seagrass colonization: biomass development and shoot demography in Cymodocea nodosa patches. Mar Ecol Prog Ser 67:97-103

Duggins DO, Simenstad CA, Estes JA (1989) Magnification of secondary production by kelp detritus in coastal marine ecosystems. Science 245:170-173

Edgar GJ (1992) Patterns of colonization of mobile epifauna in a Western Australian seagrass bed. J Exp Mar Biol Ecol 157:225-246

Eggleston DB, Etherington LL, Elis WE (1998) Organism response to habitat patchiness: species and habitatdependent recruitment of decapod crustaceans. J Exp Mar Biol Ecol 223:111-132

Eggleston DB, Elis WE, Etherington LL, Dahlgren CP, Posey $\mathrm{MH}$ (1999) Organism responses to habitat fragmentation and diversity: habitat colonization by estuarine macrofauna. J Exp Mar Biol Ecol 236:107-132

> Fahrig L (2003) Effects of habitat fragmentation on biodiversity. Annu Rev Ecol Evol Syst 34:487-515

> Fonseca MS, Bell SS (1998) Influence of physical setting on seagrass landscapes near Beaufort, North Carolina, USA.
Mar Ecol Prog Ser 171:109-121

> Fredriksen S, Christie H, Saethre BA (2005) Species richness in macroalgae and macrofauna assemblages on Fucus serratus L. (Phaeophyceae) and Zostera marina L. (Angiospermae) in Skagerrak, Norway. Mar Biol Res 1:2-19

Frost MT, Rowden AA, Attrill MJ (1999) Effect of habitat fragmentation on the macroinvertebrate infaunal communities associated with the seagrass Zostera marina L. Aquat Conserv 9:255-263

Gibson RN, Pihl L, Burrows MT, Modin J, Wennhage H, Nickell LA (1998) Diel movements of juvenile plaice Pleuronectes platessa in relation to predators, competitors, food availability and abiotic factors on a microtidal nursery ground. Mar Ecol Prog Ser 165:145-159

> Healey D, Hovel KA (2004) Seagrass bed patchiness: effects on epifaunal communities in San Diego Bay, USA. J Exp Mar Biol Ecol 313:155-174

> Heck KL, Able KW, Roman CT, Fahay MP (1995) Composition, abundance, biomass, and production of macrofauna in a New England estuary: comparisons among eelgrass meadows and other nursery habitats. Estuaries 18:379-389

> Hovel KA, Lipcius RN (2001) Habitat fragmentation in a seagrass landscape: patch size and complexity control blue crab survival. Ecology 82:1814-1829

> Hovel KA, Lipcius RN (2002) Effects of seagrass habitat fragmentation on juvenile blue crab survival and abundance. J Exp Mar Biol Ecol 271:75-98

Irlandi EA (1997) Seagrass patch size and survivorship of an infaunal bivalve. Oikos 78:511-518

- Irlandi EA, Ambrose WGJ, Orlando BA (1995) Landscape ecology and the marine environment: how spatial configuration of seagrass habitat influences growth and survival of the bay scallop. Oikos 72:307-313

> Isaksson I, Pihl L (1992) Structural changes in benthic macrovegetation and associated epibenthic faunal communities. Neth J Sea Res 30:131-140

- Isaksson I, Pihl L, Van Montfrans J (1994) Eutrophicationrelated changes in macrovegetation and foraging of young cod (Gadus morhua L.): a mesocosm experiment. J Exp Mar Biol Ecol 177:203-217

> Jelbart JE, Ross PM, Connolly RM (2006) Edge effects and patch size in seagrass landscapes: an experimental test using fish. Mar Ecol Prog Ser 319:93-102

Karlsson J, Loo LO (1999) On the distribution and the continuous expansion of the Japanese seaweed Sargassum muticum in Sweden. Bot Mar 42:285-294

> Lintas C, Seed R (1994) Spatial variation in the fauna associated with Mytilus edulis on a wave-exposed rocky shore. J Molluscan Stud 60:165-174

Mann KH (2000) Ecology of coastal waters with implications for management, Vol 8. Blackwell Science, Oxford

> McArdle BH, Anderson MJ (2001) Fitting multivariate models to community data: a comment on distance-based redundancy analysis. Ecology 82:290-297

> Moksnes PO (2002) The relative importance of habitatspecific settlement, predation and juvenile dispersal for distribution and abundance of young juvenile shore crabs Carcinus maenas L. J Exp Mar Biol Ecol 271:41-73

> Moksnes PO, Pihl L, van Montfrans J (1998) Predation on postlarvae and juveniles of the shore crab Carcinus maenas: importance of shelter, size and cannibalism. Mar Ecol Prog Ser 166:211-225

> Möller P, Pihl L, Rosenberg R (1985) Benthic faunal energy flow and biological interaction in some shallow marine soft bottom habitats. Mar Ecol Prog Ser 27:109-121

Muus BJ (1967) The fauna of Danish estuaries and lagoons. Distribution and ecology of dominating species in the shal- 
low reaches of the mesohaline zone. A. F. Håst, Copenhagen

Nelson WG (1979) An analysis of structural pattern in an eelgrass (Zostera marina L.) amphipod community. J Exp Mar Biol Ecol 39:231-264

Nohrén E, Pihl L, Wennhage H (2009) Spatial patterns in community structure of motile epibenthic fauna in coastal habitats along the Skagerrak-Baltic salinity gradient. Estuar Coast Shelf Sci 84:1-10

Norkko A (1998) The impact of loose-lying algal mats and predation by the brown shrimp Crangon crangon (L.) on infaunal prey dispersal and survival. J Exp Mar Biol Ecol 221:99-116

Norling P, Kautsky N (2007) Structural and functional effects of Mytilus edulis on diversity of associated species and ecosystem functioning. Mar Ecol Prog Ser 351:163-175

Pihl L (1986) Exposure, vegetation and sediment as primary factors for mobile epibenthic faunal community structure and production in shallow marine soft bottom areas. Neth J Sea Res 20:75-83

Pihl L (1989) Abundance, biomass and production of juvenile flatfish in southeastern Kattegat. Neth J Sea Res 24:69-81

Pihl L, Rosenberg R (1982) Production, abundance and biomass of mobile epibenthic marine fauna in shallow waters, Western Sweden. J Exp Mar Biol Ecol 57:273-301

Pihl L, Baden SP, Diaz RJ (1991) Effects of periodic hypoxia on distribution of demersal fish and crustaceans. Mar Biol 108:349-360

Pihl L, Magnusson G, Isaksson I, Wallentinus I (1996) Distribution and growth dynamics of ephemeral macroalgae in shallow bays on the Swedish west coast. J Sea Res 35: 169-180

Pihl L, Svenson A, Moksnes PO, Wennhage H (1999) Distribution of green algal mats throughout shallow soft bottoms of the Swedish Skagerrak archipelago in relation to nutrient sources and wave exposure. J Sea Res 41:281-294

Pihl L, Baden S, Kautsky N, Rönnback P, Söderqvist T, Troell M, Wennhage H (2006) Shift in fish assemblage structure due to loss of seagrass Zostera marina habitats in Sweden. Estuar Coast Shelf Sci 67:123-132

Ragnarsson SÁ, Raffaelli D (1999) Effects of the mussel Mytilus edulis L. on the invertebrate fauna of sediments. J Exp Mar Biol Ecol 241:31-43

Robbins BD, Bell SS (1994) Seagrass landscapes: a terrestrial approach to the marine subtidal environment. Trends Ecol Evol 9:301-304

Roberts DA, Poore AGB (2006) Habitat configuration affects colonisation of epifauna in a marine algal bed. Biol Conserv 127:18-26

Editorial responsibility: Josep-Maria Gili,

Barcelona, Spain
Rueness J (1989) Sargassum muticum and other introduced Japanese macroalgae: biological pollution of European coasts. Mar Pollut Bull 20:173-176

Russell BD, Gillanders BM, Connell SD (2005) Proximity and size of neighbouring habitat affects invertebrate diversity. Mar Ecol Prog Ser 296:31-38

Sargent FJ, Leary TJ, Crewz DW, Kruer CR (1995) Scarring of Florida's seagrasses: assessment and management options. Technical Report TR-1, Florida Marine Research Institute, St. Petersburg, FL

Short FT, Burdick DM (1996) Quantifying eelgrass habitat loss in relation to housing development and nitrogen loading in Waquoit Bay, Massachusetts. Estuaries 19:730-739

Sogard SM (1989) Colonization of artificial seagrass by fishes and decapod crustaceans: importance of proximity to natural eelgrass. J Exp Mar Biol Ecol 133:15-37

Stoner AW, Lewis FG III (1985) The influence of quantitative and qualitative aspects of habitat complexity in tropical seagrass meadows. J Exp Mar Biol Ecol 94:19-40

Thayer GW, Kenworthy WJ, Fonseca MS (1984) The ecology of eelgrass meadows of the Atlantic coast: a community profile. US Fish and Wildlife Service, Washington, DC

> Thomsen MS, Wernberg T, Staehr PA, Pedersen MF (2006) Spatio-temporal distribution patterns of the invasive macroalga Sargassum muticum within a Danish Sargassum bed. Helgol Mar Res 60:50-58

Tsuchiya M, Nishihira M (1985) Islands of Mytilus as a habitat for small intertidal animals: effect of island size on community structure. Mar Ecol Prog Ser 25:71-81

Virnstein RW, Curran MC (1986) Colonization of artificial seagrass versus time and distance from source. Mar Ecol Prog Ser 29:279-288

Wallentinus I (1984a) Comparisons of nutrient uptake rates for Baltic macroalgae with different thallus morphologies. Mar Biol 80:215-225

- Wallentinus I (1984b) Partitioning of nutrient uptake between annual and perennial seaweeds in a Baltic archipelago area. Hydrobiologia 116-117:363-370

Wennberg T (1987) Långsiktiga förändringar av makroflorans sammansattning och utbredning i södra Laholmsbukten sedan 1950-talet. Report No. 3290, Swedish Environmental Protection Agency, Solna

> Wennhage H, Pihl L (2007) From flatfish to sticklebacks: assemblage structure of epibenthic fauna in relation to macroalgal blooms. Mar Ecol Prog Ser 335:187-198

Zijlstra JJ (1972) On the importance of the Wadden Sea as a nursery area in relation to the observation of the southern North Sea fishery resources. Symp Zool Soc Lond 29: $233-258$

Submitted: November 13, 2009; Accepted: March 17, 2010 Proofs received from author(s): April 19, 2010 